\title{
Shear slip indication at Big Gossan Mine
}

\author{
H. Arbi PT Freeport Indonesia, Indonesia \\ E. Riyanto PT Freeport Indonesia, Indonesia \\ R. Rabbani PT Freeport Indonesia, Indonesia \\ L. Meiharrik PT Freeport Indonesia, Indonesia
}

\begin{abstract}
Big Gossan Mine is a relatively new mining operation that will produce 7,000 tons of ore per day within the greater PT Freeport Indonesia mining operations complex in the province of Papua in Indonesia. Traditionally all mining operations in the underground situation of PT Freeport have been successful block cave entities. The Big Gossan is planned as a paste filled open stope operation and is now in the initial stages of production. As this particular orebody is sited in very close proximity to the milling and concentrating plants, it is imperative to keep the virtually sheer cliffs adjacent to these infrastructures as stable as possible. It was decided that this different mining method would be the optimum in accomplishing this strategic need.
\end{abstract}

Big Gossan is a steep dipping orebody which is located between $300 \mathrm{~m}$ and 1,000 $\mathrm{m}$ from the surface (hence the cliffs). Initial geological investigations have defined two shear zones that almost parallel the orebody in its southern footwall. These shear zones will be in close proximity and/or intersect all the main service accesses to the production stopes. The stability of these structures and their influence on the integrity of the whole mining operation is a concern in the light of the strategic need to limit any unnecessary deformation within this area of the operations.

In the early stage of exploitation, mining induced stresses have caused rock wall damage to the access excavations and continual audible failure is heard by the operational workers. To this end, instrumentation is being installed and utilised to measure deformation and changes in the field stresses. In addition, a local microseismic system has been put in place to measure any seismic activity related to the effects of mining underground in the presence of weak geological structures. Emphasis is also on surface stability and this is underlined by the fact that accelerometers have been installed for this specific purpose.

At the onset, the microseismic system recorded no seismic events related to rock failure of any significance. Initial stage events recorded were only related to blasting activity. However, the microseismic system has subsequently started to record seismic events both on surface and underground. After review of some of these seismic event and investigations underground, it was observed that some of these events could be relates to slip movement along the shear zone. Visual inspection of certain areas has yielded information that there is in fact damage propagation related to seismicity, especially in the area where the shear zone intersects the footwall strike drifts.

\section{Introduction}

The intention of this paper is to review the steps that have been taken to quantify possible future displacements in the shear zone and to evaluate these in terms of their impact on future mining. In addition, this paper attempts to establish the possible progressive geotechnical hazard with regard to stress build re-distribution in the shear zones as mining progresses with time. This paper is addressed to develop action plan that should be done in geotechnical risk assessment of Big Gossan Mine to identify and minimise these effects upon the operation. 


\section{$2 \quad$ Location and history}

The Big Gossan Mine is one of the mine sites in the Contract of Work Area (COWA) of PT Freeport Indonesia. COWA of PT Freeport Indonesia is located approximately $4^{\circ} 6^{\prime}$ south latitude, $137^{\circ} 7^{\prime}$ east longitude in the Sudirman Mountain range of Papua Province (Indonesia). The Big Gossan deposit is located $1 \mathrm{~km}$ southwest of the original Ertsberg pit, about $1.5 \mathrm{~km}$ west-northwest of the PTFI Mill/Concentrator complex (Figure 1).

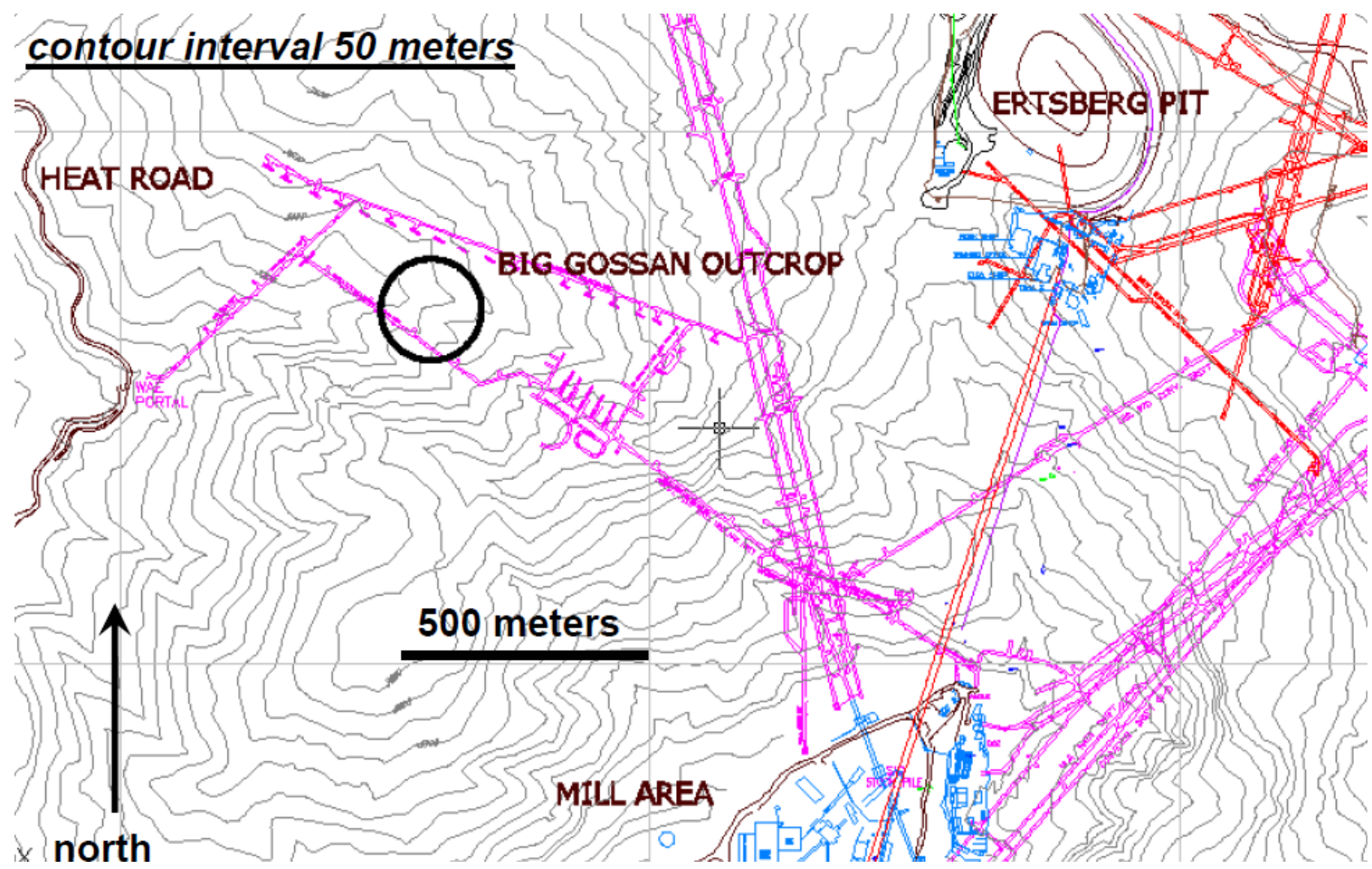

Figure 1 Big Gossan location at $3400 \mathrm{~m}$ elevation (Freeport-McMoRan Copper and Gold Inc., 2005)

The Big Gossan deposit was discovered in 1976 while conducting a helicopter reconnaissance of the area. Development of the Big Gossan Mine began in earnest some time in 2005. The first trial stope was mined in 2008. However, in line with the strategic mine plan, the open stope project was only brought on line in August of 2010. Currently, 9 stopes have been mined at a relatively low production rate of 1,500 tons of ore per day but it is planned to be increased to 7,000 tons of ore per day of ore in 2012.

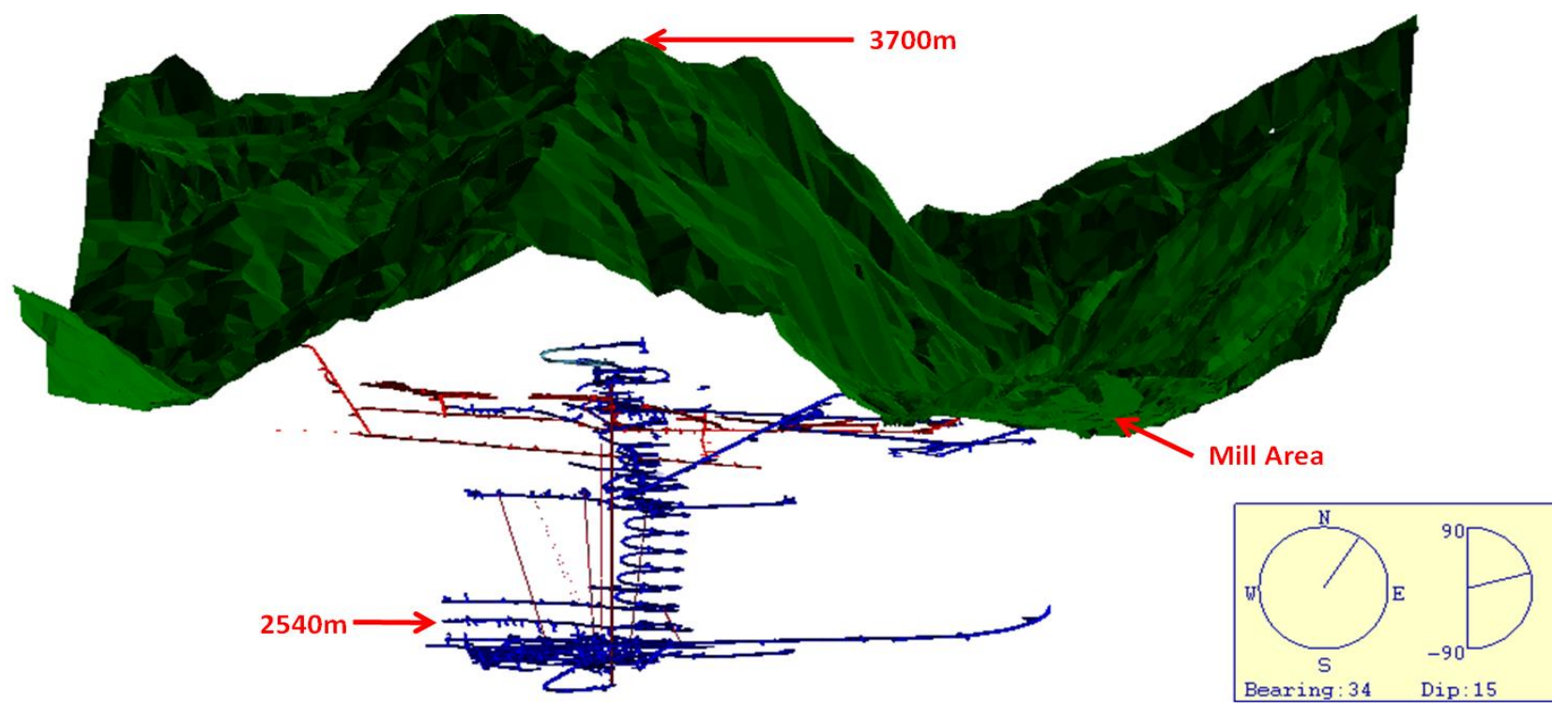

Figure 2 Big Gossan topography location (Freeport-McMoRan Copper and Gold Inc., 2005) 


\section{1 Geological setting}

The Big Gossan is a skarn-hosted copper, gold, and silver deposit. The Big Gossan is a near-vertical deposit of pyroxene-garnet-chalcopyrite skarn, hosted in the Tertiary Waripi Formation sandy dolomite unit. The deposit is relatively continuous for more than $1,200 \mathrm{~m}$ along strike and $650 \mathrm{~m}$ on a near vertical dip. The main mineralised zone ranges from about $20-100 \mathrm{~m}$ in width with an average of about $60 \mathrm{~m}$. The orebody pinches out towards the top and is generally enriched with mineralisation. The footwall service excavations are located in the Kembelangan Limestones (Kkel) and Kembelangan Hornfelsic Limestones (Kkeh) of this geological formation. The formal long term service excavations are located further to the south of orebody in Kembelangan Sandstones (Kkes) formation (Figure 3).

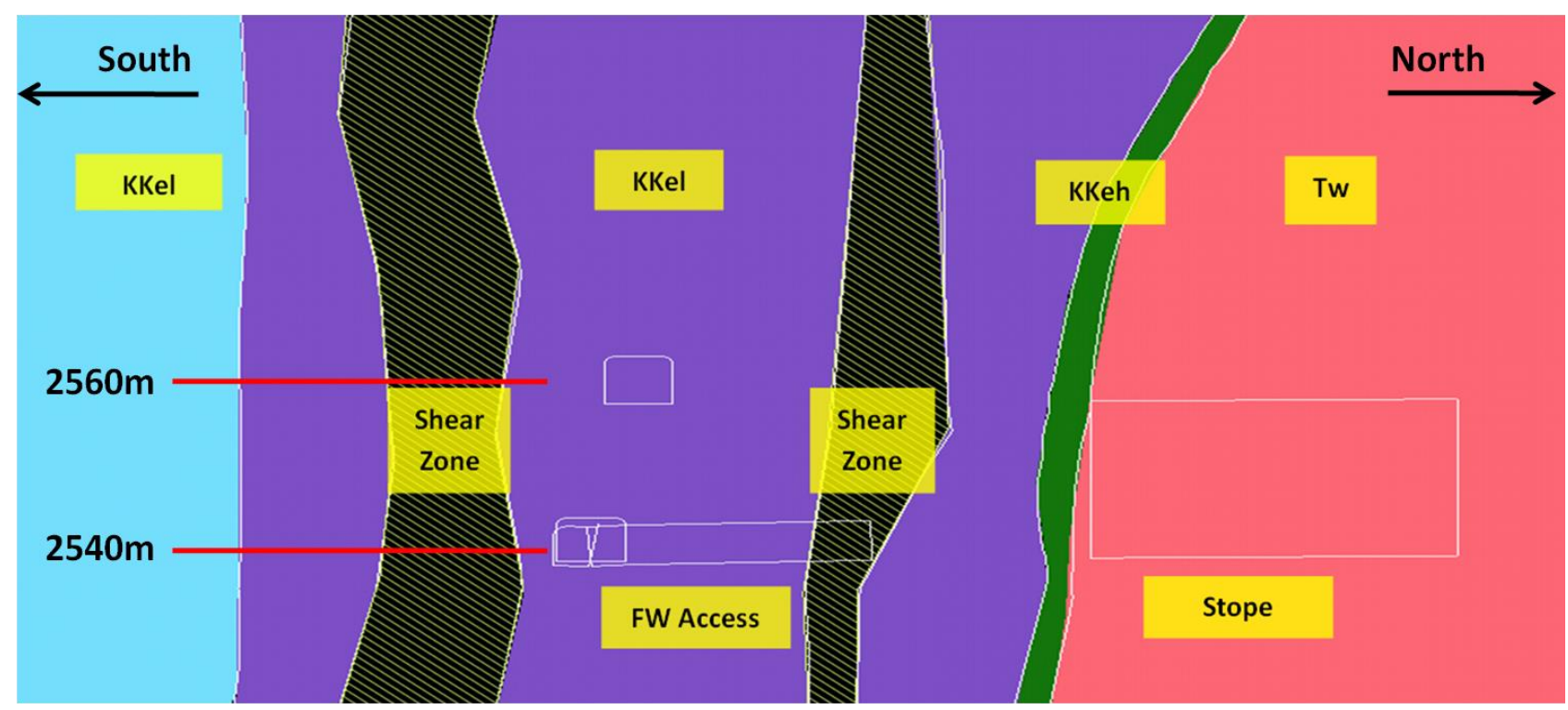

Figure 3 Schematic geology section of Big Gossan Mine

\section{2 Production and mining}

A backfill (paste) stope mining method is utilised in the Big Gossan Mine. Mining is progressing from the lowest level on 2540/L and will be completed at the top extent on 3180/L. A primary and secondary sequence is utilised to achieve the production target (Figure 3). Open stopes will be filled with paste fill from the paste plant facilities located underground on the 3000/L and 3120/L levels. The paste fill is composed of classified tailing material and is cemented to enhance its performance. The paste fill is distributed by gravity from the upper level to the open stopes by means of an open ended pipe system. 


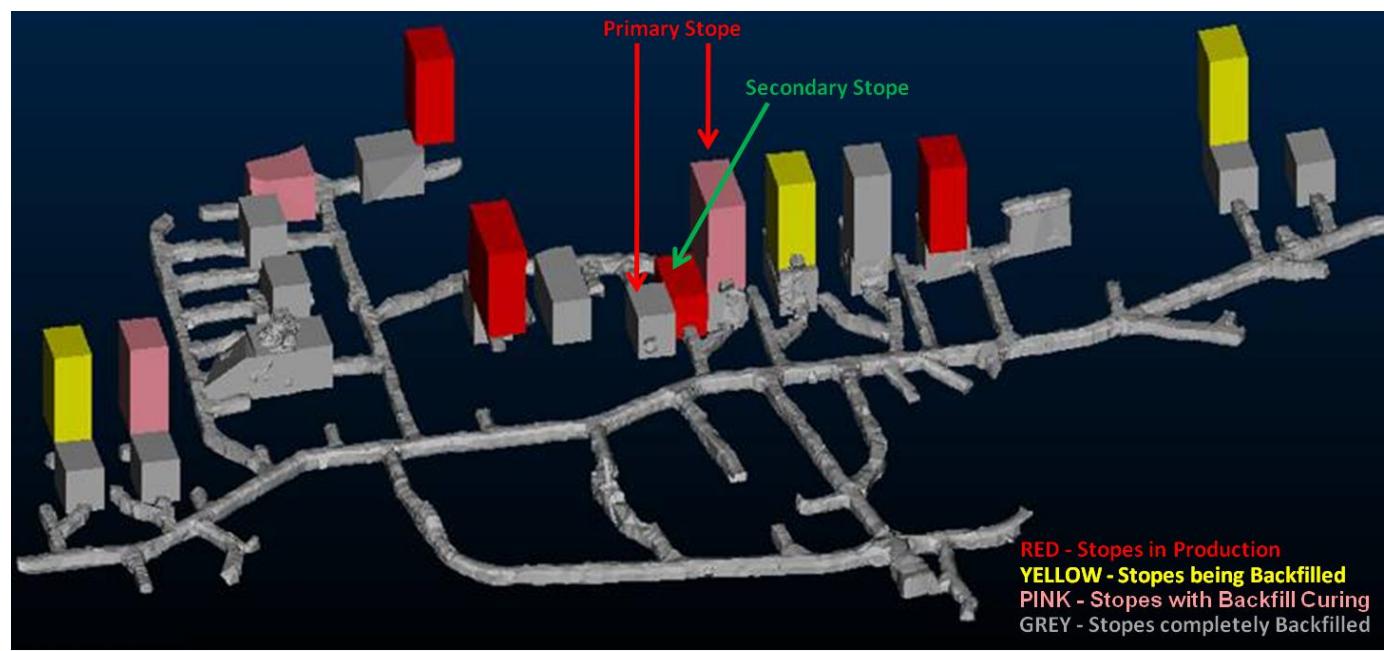

Figure 4 Big Gossan 2540L stope sequence plan (Smith, 2011)

Two shear zones are located on the south side of the orebody that intersect most of the footwall access excavations to the stopes. The shear zones are undulating subvertical features that almost parallel the strike of the orebody and general lithology of the area (Figure 5).

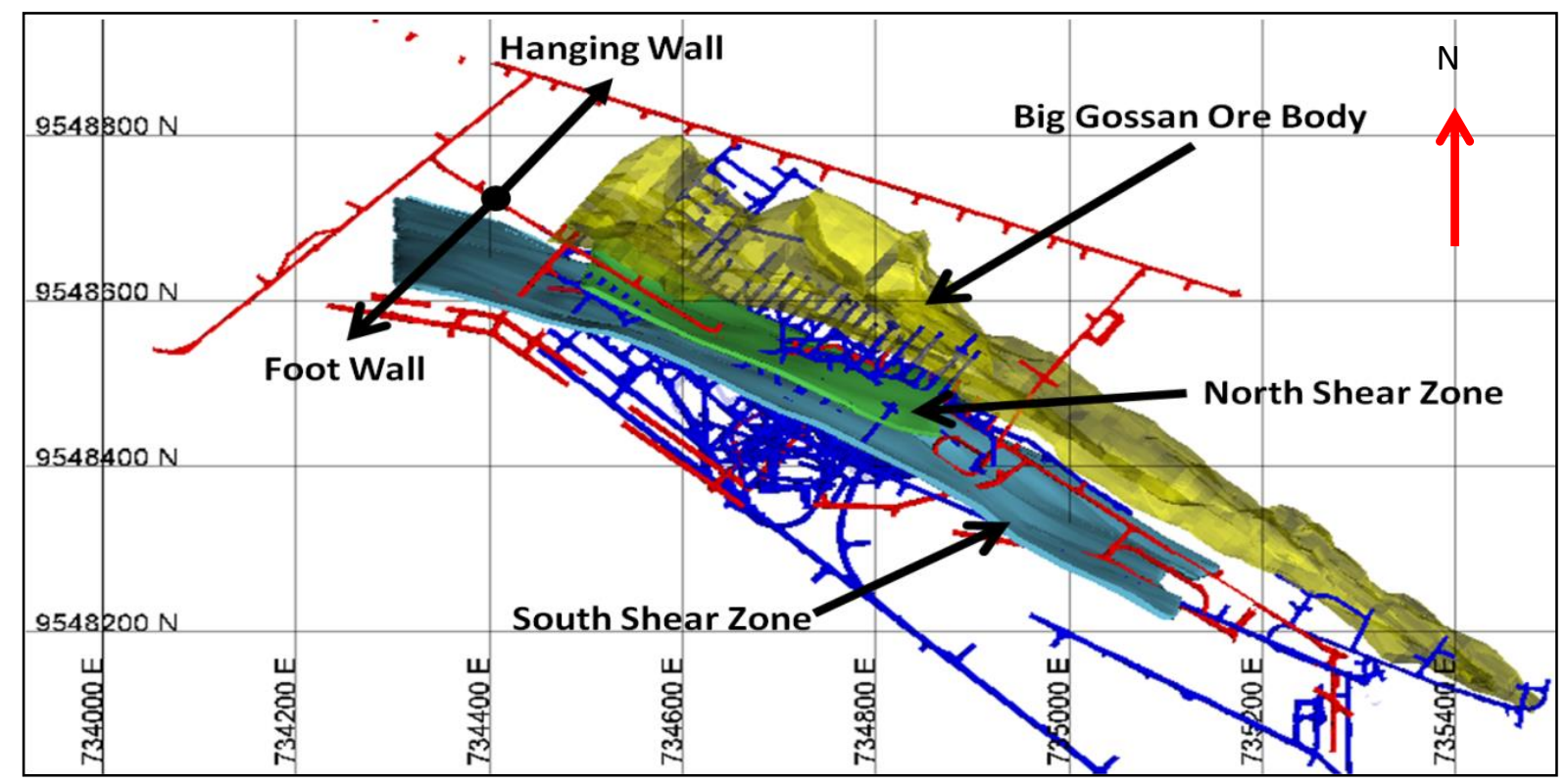

Figure 5 Big Gossan orebody and shear zone plan view

\section{3 Geotechnical consideration}

\section{3.1 Rock mass properties}

Several laboratory tests were undertaken during the feasibility study and again in 2009. Samples from each formation were collected and tested in the laboratory to establish the physical properties of the overall rock mass, specifically to establish material strength to assist in the design of footwall service excavations. Samples from this test, importantly, intersected shear zone. Based on the overall laboratory test results, the Tw formation (orebody) is the most ductile of all the material. Sample from KKel and KKeh formation indicate that this rock is quite brittle (Table 1). However, there is a wide variation apparent in all the rock properties. 
Table 1 Rock mass properties

\begin{tabular}{lcccc}
\hline \multicolumn{1}{c}{ Rock Type } & UCS (MPa) & $\begin{array}{c}\text { Young's Modulus } \\
(\mathrm{GPa})\end{array}$ & Poisson Ratio & $\begin{array}{c}\text { Density } \\
\left(\mathbf{K g} / \mathbf{m}^{\mathbf{3}}\right)\end{array}$ \\
\hline Hornfelsic (Kkeh) & $119 \pm 92$ & $60.05 \pm 17.67$ & $0.22 \pm 0.12$ & 2,753 \\
Hornfelsic limestone (Kkel) & $108 \pm 48$ & $74.77 \pm 34.92$ & $0.22 \pm 0.09$ & 2,898 \\
Waripi (Tw) & $89 \pm 80$ & $54.15 \pm 29.34$ & $0.27 \pm 0.16$ & 3,003 \\
\hline
\end{tabular}

\section{3. 2 Stress regime}

In situ stress measurements have been undertaken at three different locations and formations using the $\mathrm{HI}$ Cell Overcoring Method. As such, measurements were obtained from the KKel Formation, KKeh - Kkel Formation and Tw formation. The objective was to establish the stress regime in the fix services area, footwall access and production areas. There were two test holes utilised at each site and in each hole two cells were installed. The quality of the test results undertaken in the Tw Formation and KKes formation provided a high degree of data confidence. While test results in the KKel formation provided a low degree of data confidence as these tests were done in close proximity to the shear zone. Some cells were located in the shear zone and inconsistent results were achieved from these units (Table 2). The levels of confidence obtained from these tests, resulted in a conservative approach to mine design, especially when the data was used in numerical computer models.

Table 2 Measured principal stress (Mining Measurement Services Pty Ltd, 2010)

\begin{tabular}{|c|c|c|c|c|c|}
\hline Rock Formation & Level & Principal Stress & Magnitude (MPa) & $\operatorname{Dip}\left({ }^{\circ}\right)$ & Bearing $\left({ }^{\circ}\right)$ \\
\hline \multirow{3}{*}{ Sandstones (Kkes) } & \multirow{3}{*}{2510} & Major & 27.1 & 28 & 272 \\
\hline & & Intermediate & 19.6 & 13 & 9 \\
\hline & & Minor & 17.1 & 58 & 122 \\
\hline \multirow{3}{*}{ Limestone (Kkel) 1} & \multirow{3}{*}{2560} & Major & 37.5 & 13.3 & 61 \\
\hline & & Intermediate & 30.7 & 32.2 & 31.03 \\
\hline & & Minor & 15.1 & 1 & 151 \\
\hline \multirow{3}{*}{ Limestone (Kkel) 2} & \multirow{3}{*}{2560} & Major & 35.4 & 4 & 229 \\
\hline & & Intermediate & 23.8 & 63 & 23.8 \\
\hline & & Minor & 18.2 & 26 & 321 \\
\hline \multirow{3}{*}{ Limestone (Kkel) 3} & \multirow{3}{*}{2560} & Major & 39.5 & 15 & 67 \\
\hline & & Intermediate & 28.1 & 71 & 207 \\
\hline & & Minor & 18.2 & 12 & 334 \\
\hline \multirow{3}{*}{ Dolomite (Tw) } & \multirow{3}{*}{2560} & Major & 33.9 & 27 & 247 \\
\hline & & Intermediate & 27.9 & 53 & 115 \\
\hline & & Minor & 25.5 & 24 & 349 \\
\hline
\end{tabular}




\section{$4 \quad$ Monitoring system}

\section{1 Monitoring system}

PT Freeport Indonesia installed a microseismic ground monitoring system and ground accelerometer monitoring units in the Big Gossan Mine. These systems have been installed in the mine since August 2010. The monitoring systems were installed for different reasons which will be explained later. However, these two systems complement each other and reliable information is recorded.

The microseismic system was installed to monitor seismicity in the mine caused by the general dynamics of mining activity and its effect upon the natural environment (i.e. movement of geological structures). Fourteen sensors were installed and they are positioned in a consistent manner within the Big Gossan Mine to record seismic events over the whole mining footprint. The system was obtained from ESG as it was considered that this was best suited to monitor this site. The system records all of the events, induced by mining and those from direct blasting activity.

There are dams situated in and around the Big Gossan Mine. Five ground accelerometers are installed close to the dam walls in order to give early warning should there be any ground movement that could cause damage to the structures. Two additional accelerometers are installed on surface at the Bali Dam and Upper Manado to monitor ground movement as a result of surface earthquakes.

These two systems often record the same event in time. When this happens, visual observations are carried out to establish the impact upon the mine infrastructure and these data are utilised to continually calibrate the monitoring systems.

\section{2 Indication of slip based on seismic events}

In the early stages of Big Gossan's operations, there was a fair amount of seismic activity enveloping the shear zones. Of these, the seismic events that were triggered by slip movement in the shear zones were determined, based upon the focal mechanism method or seismic energy. These analyses indicated that the ratio of Es (energy which is resulted by shear wave) to Ep (energy which is resulted by pressure wave) can be used as a robust method to determine failure mechanism (SiM Mining Consultants (Pty) Ltd, 2009). It was established that slip on the shear would occur when:

$$
\text { Es/Ep } \geq 10 \text { or when Log (Es/Ep) } \geq 1 \text { (Figure 6) }
$$

where:

$\begin{array}{ll}\text { Es } & =\quad \text { energy which is resulted by shear wave (Joule). } \\ \mathrm{Ep} & =\quad \text { energy which is resulted by pressure wave (Joule). }\end{array}$

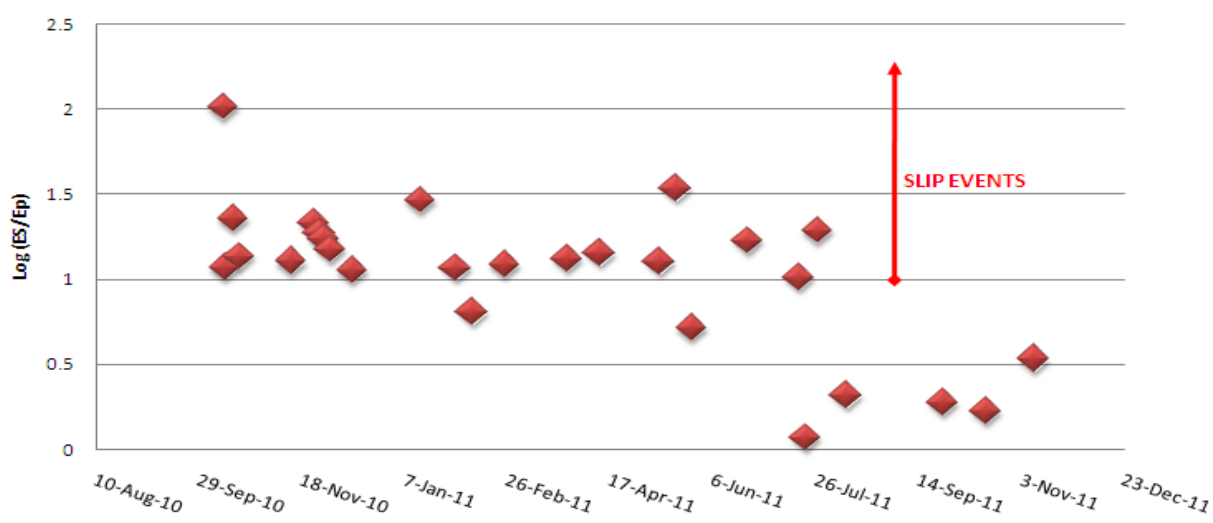

Date

Figure 6 Value of Log (Es/Ep) from seismic event that happened between September 2010 and November 2011 
From September 2010 until November 2011, 159 events were recorded in the Big Gossan Mine. From all of those events recorded, there were only 20 seismic events which were categorised as shear slip events based upon the Es/Ep criteria. Plotting of the seismic event information indicated that almost all of the shear slip events happened at Eastern side of Big Gossan Mine (Figure 7). Of these events, most of shear slip events happened on or around the south shear zone. The highest magnitude of these shear slip events was +0.51 and this event happened near the south shear zone. The magnitude of this event relative to the area events can be classified in the medium range. However, this event happened in an area where mining activity is still at the early stage of mining and far away from mined excavations.
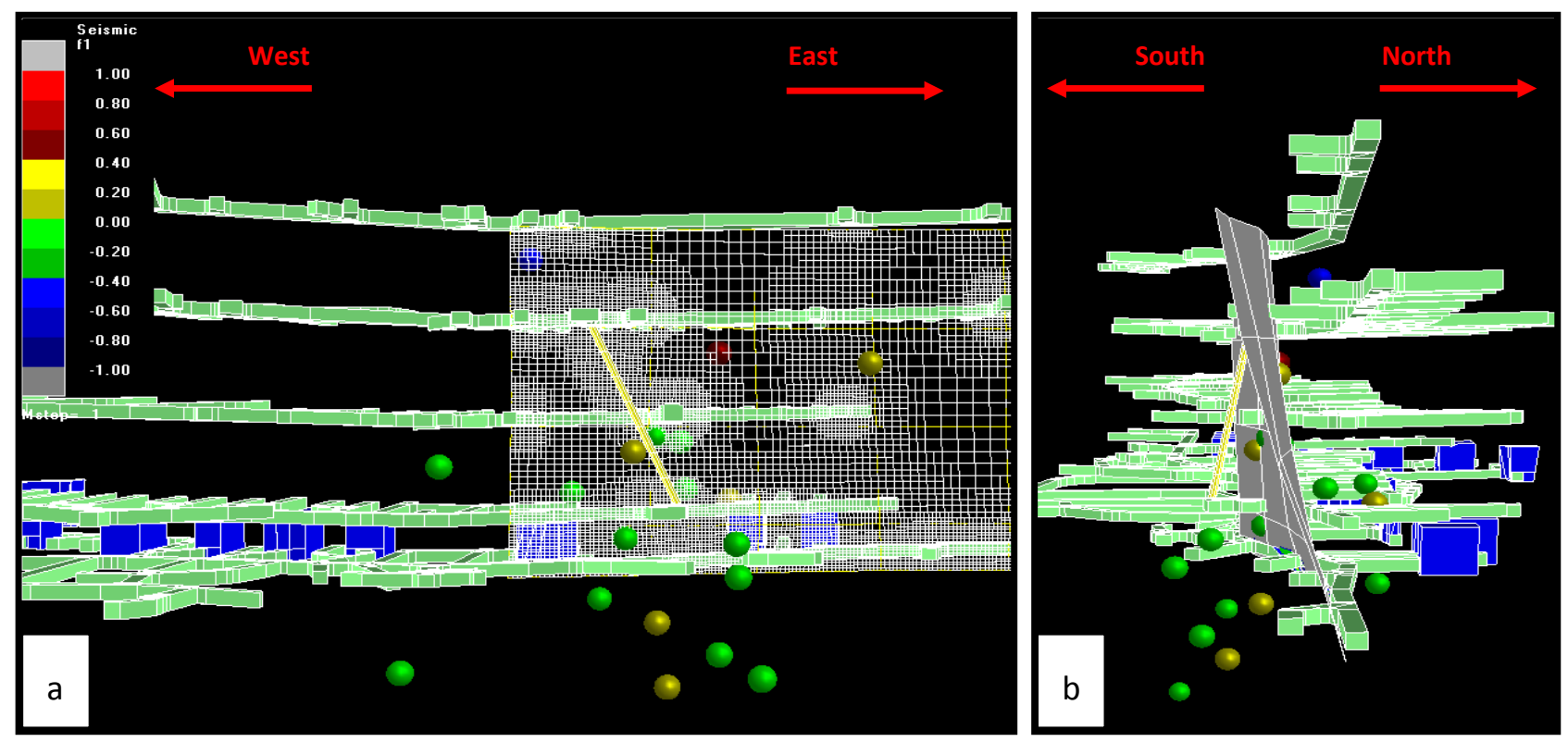

Figure 7 Distribution of shear slip events in Big Gossan Mine a) West - East Section b) North South Section

\section{3 Damage mapping}

Besides the seismic monitoring and analysis, damage mapping was also performed on a regular basis to observe the ground response caused by mining activities. Damage along the footwall access was first noted in 2009. Damage was observed on the lower rib of drift on 2560/L. In the beginning, it was assumed that the damage was caused by high vertical stresses since damage mostly occurred along the rib. Result from damage mapping along the newly opened up footwall access has indicated that damage only took place at particular area in portions of the footwall access. An analytical review was undertaken by overlaying the drift design upon the geological structures and mapped damage locations. This analysis indicated that most damage along the footwall access was present when the shear zone intersected the footwall access drive. During the development activities, rock wall damage was always observed when the shear zone intersected the footwall access. Micro damage is usually observed when the drift intersects the shear zone perpendicularly. Light to moderate damage is usually observed when the drift is parallel to the shear zone and/or is intersected by the shear zone (Figure 8). Light damage was generally observed on the western side of mine, while moderate damage was mostly observed at the eastern side of mine. 


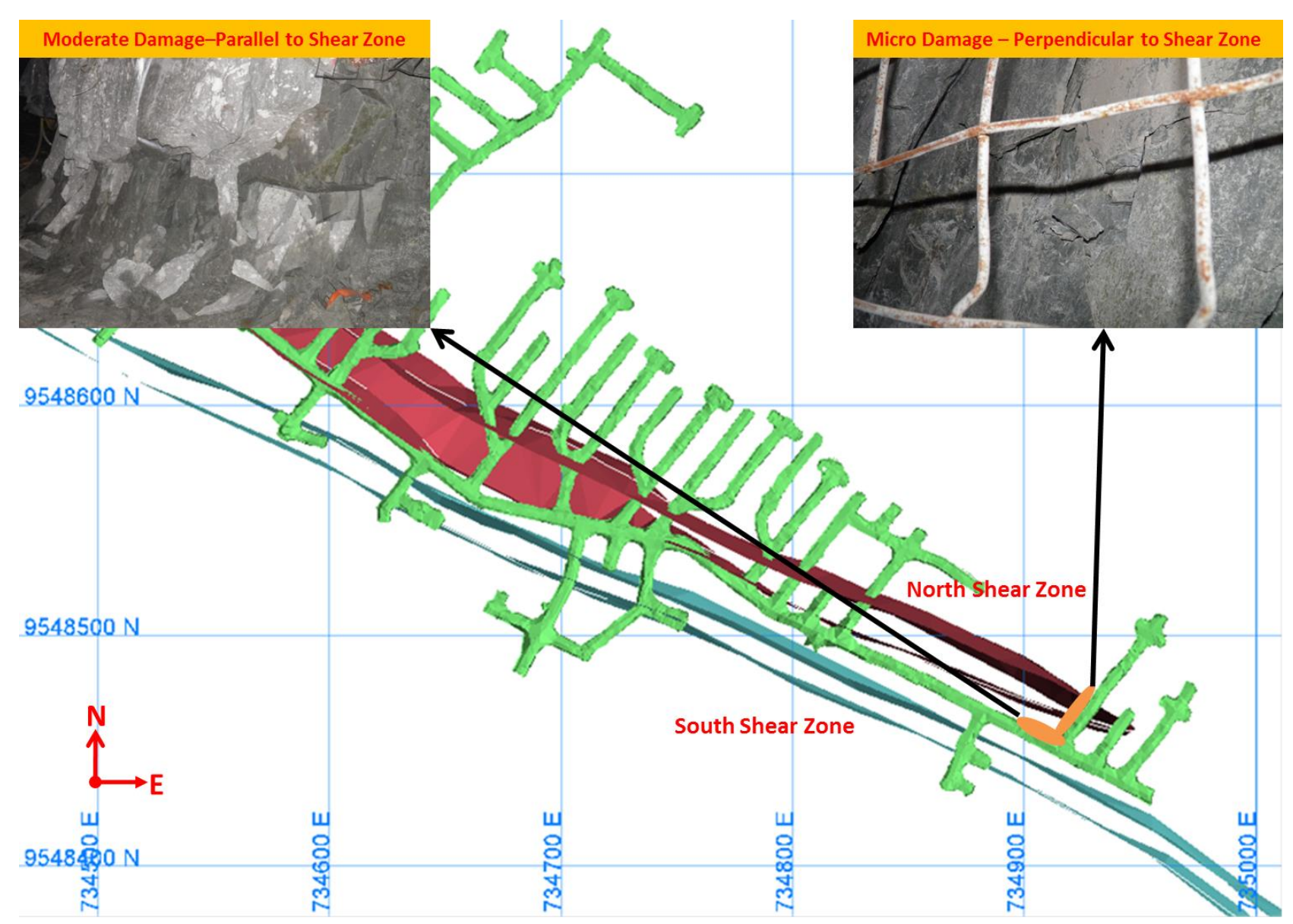

Figure 8 Micro and moderate damage at cross cut $432560 \mathrm{~L}$

\section{4. $4 \quad$ Numerical modelling}

Map3D (Elastic modelling) was used to simulate mining induced stress conditions in the Big Gossan Mine in relationship to geological features. In the model, mine openings such as drifts and stopes, as well as the shear zones, were included in the analysis. Mining simulation was limited to only excavations between 2540 and 2680 Level. A grid surface plane was used to describe the shear zone surface. This grid was located where the shear zone intersected all the critical areas. In slip failure mode, failure will be influenced by excess shear strength (Ryder, 1988).

$$
E S S=\tau-\left(C+\mu \sigma_{n}\right)
$$

where:

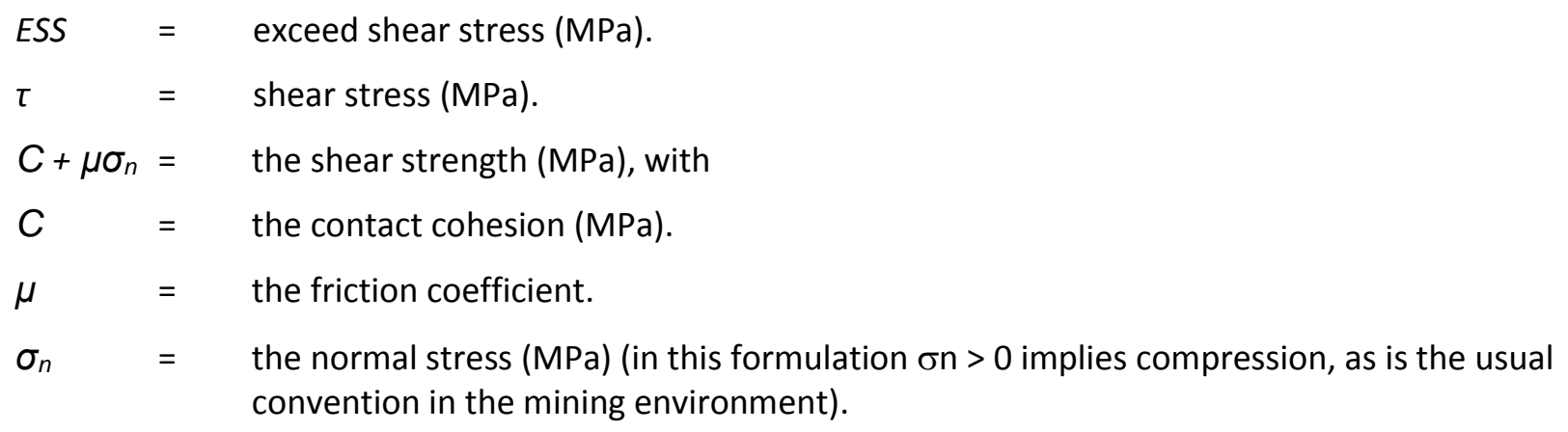

The simulation was run in the elastic mode where failure would start to happen when ESS $=0$. Damage would be expected to take place when the ESS has a positive value. The model was simulated in two stages. The initial stage was the current scenario where some damage and seismic events have started to happen. 
Shear stress and normal stress in the location where damage or seismic events have happen will be the focus of this model. These data will be utilised to try and predict the properties of shear zones relative to critical ESS values where damage is propagated. The next stage was to simulate the inclusion of mining by stage or stope sequences and compare the outcome with the same related structures as focused in the first simulation.

Recorded microseismic events and data obtained from damage mapping are important to verify the shear strength of structure before the ESS is calculated. The value of the shear stress and the normal stress that works on a structure plane depends upon the orientation of structure in space. General orientation of structures measured from structural mapping was used as an input in model to satisfy the simulation's needs to determine ESS value as well as the friction angle and cohesion.

Friction angle can be retrieved from the model by using formula (Wiles et al., 2000):

$$
\theta=\tan ^{-1}\left((\tau-C) / \sigma_{n}\right)
$$

where:

$\theta=$ friction angle.

$\tau \quad=\quad$ shear stress (MPa).

$C=$ cohesion (MPa); cohesion can be assumed to be zero (in dynamic state).

$\sigma_{n} \quad=\quad$ the normal stress (MPa).

As previously stated, the analysis was focused on the south shear zone since most of the seismic events happen in that area of the mine. For the south shear zone, with general orientation (D/DD) $85^{\circ} / 20^{\circ} \mathrm{NE}$, the friction angle that is required by the shear zone to resist movement is in the range of $27-36^{\circ}$. Some numbers in this range were chosen and used to calculate ESS value along the shear zone. The results were compared with observed damage underground and also recorded seismic events data. It was noted that, $29.8^{\circ}$ is the most acceptable friction angle number for the prevailing situation. By using this number in the ESS equation, ESS has a positive value in the area where seismic events and damage were observed.

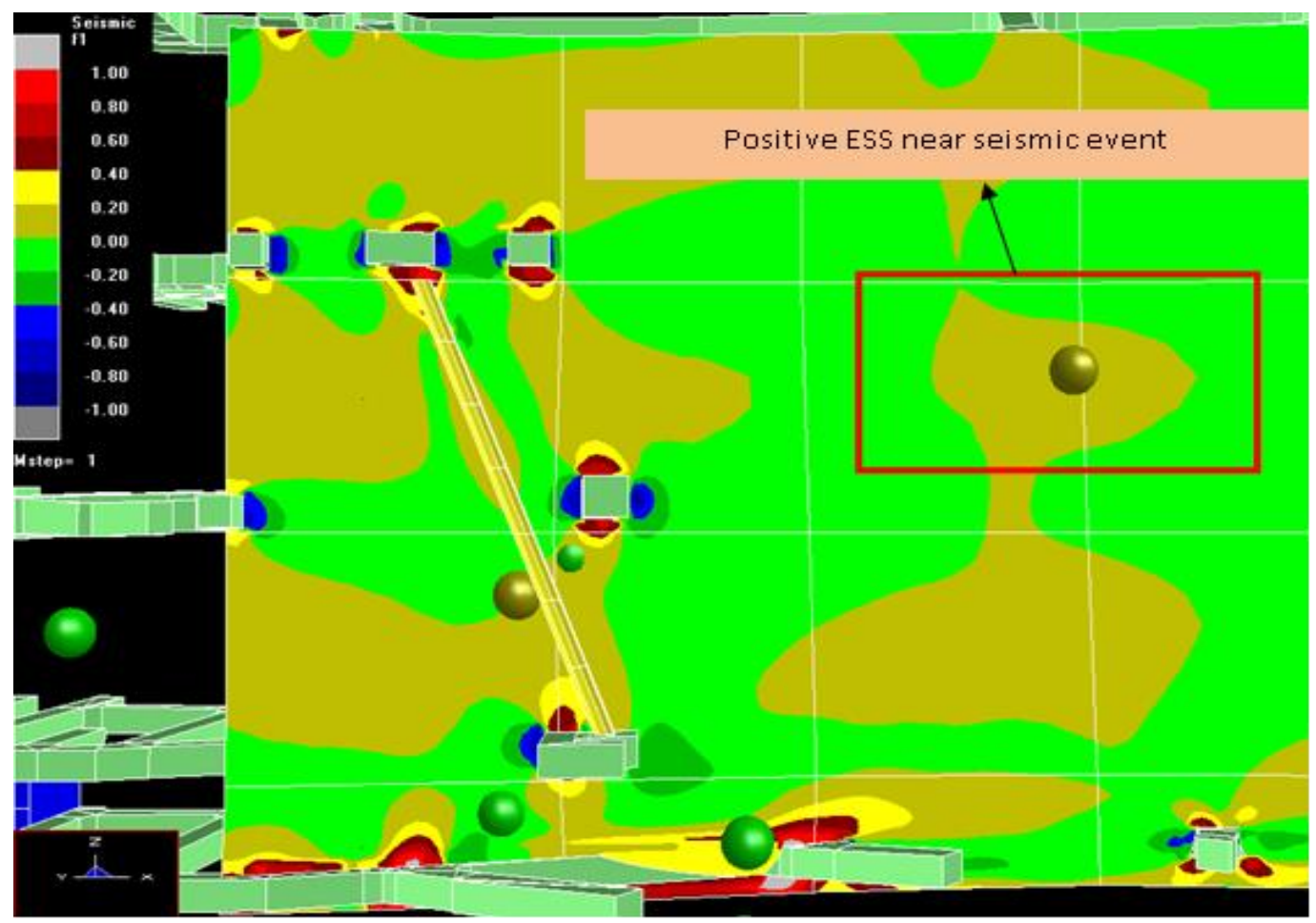

Figure 9 ESS contour on south shear zone and distribution of seismic events around south shear zone 
Ground response to a positive ESS value depends on the degree of ESS value and also the area of $\left(\mathrm{m}^{2}\right)$ ESS contour on the shear surface. The strength of energy released providing a positive ESS value can be predicted theoretically (Figure 9). A robust estimation can be made to determine the seismic moment by assuming that the geometry of ESS contour is spherical. The seismic moment $\mathrm{M}_{\mathrm{o}}$ can be determined by using Equation (4) (Ryder and Jager, 2002):

$$
M_{0}=1.7 \times E S S \times a^{3}
$$

where:

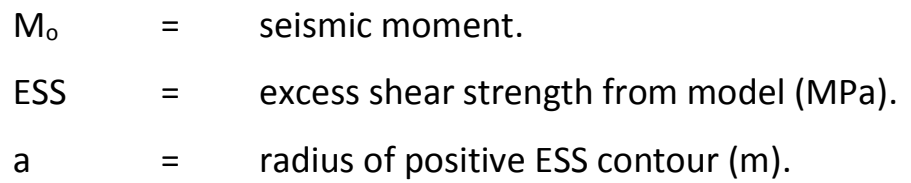

The magnitude of a seismic event (M) can be calculated by using Moment Magnitude equation (Hanks and Kanamori, 1979)

$$
M=\left(2 / 3 \times \log 10\left(M_{0}\right)\right)-6
$$

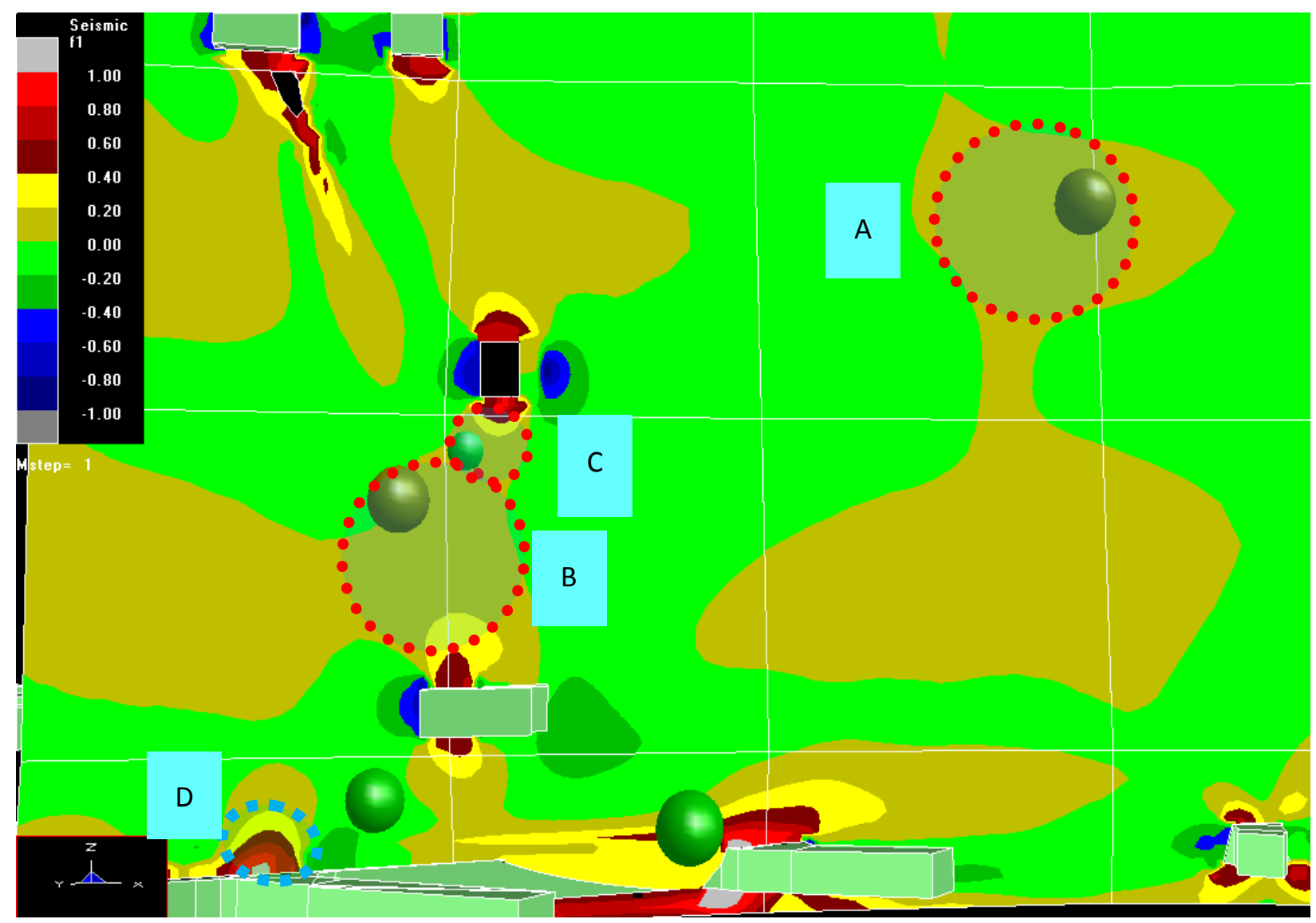

Figure 10 Estimation of average ESS and radius in the area where positive ESS concentrate on shear plane

The ESS contour results from the simulation have been overlaid upon the seismic events and physically observed structural damage underground. An imaginary circle was created on the positive ESS contour where the seismic events and damage happened. An estimated circle radius and also average ESS in this imaginary circle can be determined. Equations (4) and (5) are then used to estimate $M_{o}$ and $M$ by using an average ESS and radius from this information. 
The result of these calculations for the four areas in Figure 10 is summarised in the Table 3 below:

Table 3 Seismic magnitude calculation based on average ESS

\begin{tabular}{cccccc}
\hline Location & $\begin{array}{c}\text { Average ESS } \\
(\mathbf{P a})\end{array}$ & $\begin{array}{c}\text { Estimated a } \\
(\mathbf{m})\end{array}$ & Calculated Mo & $\begin{array}{c}\text { Calculated } \\
\text { Magnitude }\end{array}$ & Actual \\
\hline A & $3.00 \mathrm{E}+05$ & 14 & $1.40 \mathrm{E}+09$ & 0.097 & 0.06 \\
B & $2.50 \mathrm{E}+06$ & 5.7 & $7.87 \mathrm{E}+08$ & -0.069 & -0.07 \\
C & $5.00 \mathrm{E}+05$ & 11 & $1.13 \mathrm{E}+09$ & 0.036 & 0.01 \\
D & $7.00 \mathrm{E}+06$ & 3.5 & $5.10 \mathrm{E}+08$ & -0.195 & Audible failure \\
\hline
\end{tabular}

The table above indicates that the resulting estimations almost approach that of the magnitude recorded from seismic events (Location A, B and C). At location D, which is closed to a mined opening, there was no recorded seismic event. However, audible rock failure was heard and physical failure observed during the development stage.

Reviewing of ESS value on the shear zone (by incorporating seismic events information and observed damage) indicate that there is slip movement on the shear which is happening in the early stage of mining. Figure 10 indicates that there is an additional ESS concentration which could very well trigger another seismic event.

\section{$5 \quad$ Action plan}

Reviewing seismicity data and ground response in the initial stage of mining has provided valuable information. Back analysis of the available data can support better strategies to predict seismicity in the mine. Numerical analysis performed earlier did not integrate geological structures with the orebody in the simulation and analysis. In addition, no cognisance of any stope opening (changing stress flow in a normal direction to the shear zone) was recorded as it was required to increase the resistance of shear zone from slip. Some action plans that need to be incorporated therefore in the geotechnical risk assessment are:

1. Integration of the main geological structure in the analysis of stope sequence.

2. Structural mapping must be performed in more detail to delineate the continuity of shear zone, vertically and horizontally.

3. Data from seismic events and damage mapping should not be treated separately from other geotechnical monitoring. Any event or damage should be reviewed to identify the mechanism causing it.

4. Model calibration must be performed regularly in relation to the increasing number of seismic data and observed damage.

5. More attention must be given in the critical area such as footwall access and also nose pillar. Due to mining progress, the ESS value can increase suddenly and drop in the next step. Ground support requirements must be reviewed with regards to stress changes and life time of the opening.

\section{Summary}

There are several conclusions based on actual seismic data, observed damage and numerical modelling analysis, such as:

1. There are indications of shear slip in Big Gossan Mine, especially in the south shear zone.

2. Seismic events and observed damage correlated to the ESS can be used to confirm the possibility of shear slip events. 
3. An ESS positive contour can be used to predict the magnitude of seismic events.

4. This type of analysis will be used to review ground support requirements each time the stope sequence advances.

\section{Acknow l edgements}

The authors thank the underground geotechnical and hydrology management and PT Freeport Indonesia management for granting permission to publish this paper.

\section{References}

Freeport-McMoRan Copper and Gold Inc. (2005) Feasibility study for Big Gossan Mine, executive summary and report, Vol. I. Hanks, T. and Kanamori, H. (1979) A moment magnitude scale, Journal of Geophysical Research, Vol. 84, pp. 2348-2350.

Mining Measurement Services Pty Ltd (2010) PT Freeport Indonesia Big Gossan Rock Stress Measurements, Victoria, Australia.

Ryder, J.A. (1988) Excess shear stress in the assessment of geologically hazardous situations, Journal of the South African Institute of Mining and Metallurgy, Vol. 88, No. 1, pp. 27-39.

Ryder, J.A. and Jager, A.J. (2002) A textbook on rock mechanic for tabular hard rock mines, SIMRAC, Johannesburg, South Africa. SiM Mining Consultants (Pty) Ltd (2009) Training manual, Specific outcomes for mine seismology, Potchefstroom, South Africa. Smith, M. (2011) Production Stoping Sequence June 2011, Big Gossan engineering report.

Wiles, T.D., Lachenicht, R. and van Aswegan, G. (2000) Integration of deterministic modelling with seismic monitoring for the assessment of the rockmass response to mining: Part I Theory, in Proceedings Sixth International Symposium on Rockburst and Seismicity in Mines (RaSiM6), Y. Potvin and M. Hudyma (eds), 9-11 March 2005, Perth, Australia, Australian Centre for Geomechanics, Perth, pp. 379-387. 